\title{
Exploring the Causes of English Language Speaking Anxiety among Postgraduate Students of University of Balochistan, Pakistan
}

\author{
Nazeer Ahmed ${ }^{1}$, Zahid Hussain Pathan ${ }^{1} \&$ Faria Saeed Khan ${ }^{1}$ \\ ${ }^{1}$ Institute of English Language \& Literature, University of Balochistan, Quetta, Pakistan \\ Correspondence: Zahid Hussain Pathan, Institute of English Language \& Literature, University of Balochistan, \\ Quetta, Pakistan. E-mail: pathanzahid82@yahoo.com
}

Received: October 28, 2016 Accepted: December 5, 2016 Online Published: January 19, 2017

doi:10.5539/ijel.v7n2p99 URL: http://dx.doi.org/10.5539/ijel.v7n2p99

\begin{abstract}
English language enjoys its glory as an official language of Pakistan and it is used widely as a medium of instructions across educational institutes. Since anxiety retards the learning process, therefore it has been widely researched in the world and seems under researched in Pakistani context. Thus, the prime aim of this research is to explore the factors that cause English language speaking anxiety among Postgraduate Students of University of Balochistan (UoB), Pakistan. This study also aimed at determining the statistical significant difference if any across gender. The quantitative research design was employed in which a questionnaire comprising of eighteen items was adapted from the study by Horwitz et al. (1986). Both descriptive and inferential statistics were performed in the SPSS (version, 21). The findings revealed that UOB students were experiencing anxiety due to myriad factors in EFL classroom. The findings of the t-test revealed no statistical significant difference across gender. This paper has implications on both teaching and learning of English as a foreign language in Pakistani context.
\end{abstract}

Keywords: speaking anxiety, inter-language meaning system, inter-language grammar, inter-language phonology

\section{Introduction}

Learning English has become the dire need of the students in different countries of the world especially where the medium of instructions in education setting is English. The growing demand for communication on international level has earned English language the status of language of communication. "The ever-growing need for a good communication skill in English language has created a huge worldwide demand for achieving a good demand of English among its non-native speakers around the globe” (Mehmoodzadeh, 2012, p. 466).

Keeping in view the key importance of English language in Pakistan, students start learning English at school level and continue learning till tertiary level. Besides learning English for years, they face numerous difficulties in terms of making communication in English language. Awan, Azher, Anwar, \& Naz, (2010) asserted that it has always been a problem for Pakistani students to learn English well in an atmosphere where they are in contact with the language only in teacher centered-classroom which means that the teachers dominate in classroom and students get few chances to practice language. The past research studies have also determined that such environment makes it difficult for the students to take keen interest in the language learning process. Many students when asked to perform in foreign language, they become anxious and find it difficult to speak fluently. Öztürk (2009) conducted a mixed method study on 383Turkish EFL preparatory program students at a state university. The quantitative results revealed that students experienced a low level of speaking anxiety; however, the results of the interviews showed that the majority of the participants reported speaking skill as the main cause of anxiety. $\mathrm{Na}$ (2007) states that FL anxiety makes students become discouraged and they lose confidence in their potential to learn the foreign language (FL). Hence they avoid participating in classroom language activities and it leads to giving up learning foreign language. According to Spolsky (1989), "the learner's metacognitive awareness of his/her inability to speak fluently and understand the full message given in the FL may lead him/her to despair, hesitation, rejection of any communication activity." In the same vein, Abu-Rabia (2004) (as cited in Horowitz et al., 1986) states, "oral communication skills are more likely to be affected by language anxiety where the learner is afraid of spontaneous communication in the FL."

In EFL countries such as Pakistan, English is used in classrooms only and students do not get more opportunities 
outside the classroom to practice English language. Due to few chances to practice the foreign language, students hesitate when speak English. Abu-Rabia (2004) describes, "FL anxiety may negatively influence motivation, level of performance and attitude to learning a specific topic". Since English language is considered as the key to get employed on the good positions in Pakistan, Pakistani students put endless efforts to learn the English language especially speaking skills. However, despite studying English for years, they fail to acquire fluency in the target language due to many anxiety factors. Keeping in view the pivotal importance of the role of anxiety in learning foreign language, it has become an important subject for researchers. Past research studies on foreign language anxiety indicate that anxiety affects the speaking ability of the learners. Zheng (2008) asserts, "Language learning experience could become a traumatic experience and may deeply disturb one's self-esteem or self-confidence as a learner". "Most of the learners express their fears and a feeling of uneasiness against learning English as a foreign language" (Awan et al., p. 33).

The prime purpose of this study is to explore the causes of anxiety in learning foreign language i.e., English among postgraduate students of University of Balochistan, Pakistan and across gender. At the University, postgraduate students pay much attention to learn English language for they regard English language the key to success for their academic and personal grooming. Moreover, all the postgraduate students study English as a compulsory subject since the medium of instructions at the university is English language. Exploring the causes of English speaking anxiety would likely to pave a way for EFL teachers in Pakistan to devise strategies to help students cope with this problem.

\section{Importance of the Study}

Anxiety has been found the alarming factor causing debilitating effects on foreign language learning process. Moreover, researchers describe anxiety as one of the most prevalent phenomena which obstructs the language learning outcomes as "anxiety may affect the quality of an individual's communication or willingness to communicate," (Young, 1991, p. 58). It is believed that anxiety has been a painful experience for some learners in the process of learning foreign languages. Previously it was believed that language anxiety appears as a result of other types of anxiety such as test anxiety, trait anxiety or oral communication anxiety (Scovel, 1991). Later researchers agreed that language anxiety is independent on other types of anxiety and it is unique and distinct. Oh (1990) considers foreign language anxiety as situation specific anxiety and states, "foreign language anxiety is situation specific anxiety which students experience in classroom. It is characterized by self-centered thoughts, feeling of inadequacy, fear of failure, and emotional reactions in the language classroom", (p. 56).

The past studies have determined many causes of foreign language speaking anxiety. For example, students' communication apprehension may stem from previous negative experience (Price, 1991), shyness or reticence (Friedman, 1980), attitudes of classmates and cultural stereotypes, and foreign teacher etc. (Timina, 2015). Fear of negative evolution emanated anxiety factor for Chinese and Taiwanese students. They preferred remaining silent because they feared losing face in front of their peers when their speaking mistakes were highlighted by the teachers (Iftimie, 2006). The findings of the study by Timina (2015) revealed that that the majority of the Taiwanese university first year students were reluctant to speak English loudly due to the fear of not getting or misunderstanding the teachers' queries or tasks. The findings reported that the students also complained that English language teachers speak too fast and use many difficult words. These factors are likely to cause anxiety among foreign language learners. Similarly the study by Tercan \& Dikilitas (2015) was carried out among 159 Prep class students to find out to what extent proficiency level, gender, and onset of learning affect foreign language speaking anxiety. The findings asserted that the degree of speaking anxiety differ in terms of mode and context of speaking. Students experienced relatively less anxiety in contexts where they found themselves less threatened. Bozavli \& Gulmez (2012) asserted that in a language classroom, the activity of speaking by a learner in front of the class provokes anxiety which means that the foreign language anxiety is closely related with the verbal aspects of the language learning. Majority of the learners become anxious when they are asked to perform in the foreign language in front of their class (Young, 1990; Daly, 1991).

Dalkilic (2001) attributed conspicuousness as one of the leading causes of foreign language speaking classroom anxiety. The term conspicuousness has been defined Daly \& Buss (1984) as the preference of most of the learners not to be the focus of attention when they feel themselves less proficient at speaking. The feeling of conspicuousness is heightened when the learners are anxious of making error. According to Dalkilic (2001), lack of confidence also causes an acute anxiety among foreign language learners. On the contrary, Dalkalic (2001) considers shyness and the lack of knowledge as the prime causes responsible for the increase in foreign language speaking anxiety among learners. Phillips (1999) stated that anxiety among foreign language learners also emerge due to deficiency in their speaking skills in the target language. Horwitz, Horwitz, \& Cope (1991) added that anxiety may arise when a learner finds himself or herself in difficulty to engage in genuine communication 
when his or her linguistic skills are not up to the mark.

Based on the above reviewed existing knowledge on foreign language anxiety in general and foreign language speaking anxiety in particular, the following research questions were formulated:

1). What are the factors causing English speaking anxiety among postgraduate students of University of Balochistan, Pakistan?

2). Is there any statistical significant difference in English speaking anxiety factors between male and female postgraduate students of University of Balochistan, Pakistan?

\section{Research Methodology}

Survey Research Design was used to carry out the study. According to Creswell (2002), "Survey Research designs are procedures in quantitative research in which investigators administer a survey to a sample or to entire population of people to describe the attitudes, opinions, behaviors, or characteristics of the population," (p. 376). Gay \& Mills (2011) define survey research as "A survey is an instrument to collect data that describes one or more characteristics of a specific population," (p. 175).

\subsection{Data Collection Instrument}

This study adapted a questionnaire on Foreign Language Classroom Anxiety Scale (FLCAS) designed by Horwitz, Horwitz, \& Cope (1986). The questionnaire comprised of 33 items but only 18 items were included in the final questionnaire of this study since they solely accentuated on foreign language speaking anxiety (Mehmoodzadeh, 2012). The Cronbach's Alpha for these items was $\alpha=0.80$. All the 18 items were based on three constructs: inter-language phonology (focuses on the phonetic aspects of language), inter-language grammar (focuses on the synthetic aspects of the language) and inter-language meaning system (focuses on the semantic and pragmatic aspects of the language). The questionnaire comprised of two parts. The first part comprised of demographic information of the participants and the second part comprised of items based on five-point Likert-Scale. The following Table 1presents the distribution of items in the questionnaire:

Table 1. Division of FLCA scale speaking anxiety (Items=18)

\begin{tabular}{ll}
\hline Foreign Language Anxiety Factors & No. of Items in the Questionnaire \\
\hline Inter-language Phonology & $1,4,7,10,13,16$ \\
Inter-language Grammar & $2,5,8,11,14,17$ \\
Inter-language Meaning System & $3,6,9,12,15,18$ \\
\hline
\end{tabular}

\subsection{Research Participants}

The questionnaire was administered among 240 postgraduate students (120 male and 120 female) of University of Balochistan, Pakistan studying in different disciplines. All these students were taking the course of "Functional English Language" that aims to help them foster their all four skills of English language.

\subsection{Data Collection Procedure}

Prior to data collection, the researcher sought consent from the head of the departments. Students were also informed of the nature of the study and they were assured that their participation is voluntary and their names would not be revealed in the publication of this research. After seeking the consent of the research participants, the questionnaire was distributed among them and they were directed to fill up the questionnaire in the presence of the researcher. All the research participants were assured that they will be given the access to this study once it is completed and published online. All the participants responded to the questionnaire and handed over to the researcher.

\subsection{Data Analysis Method}

In order to answer the first research question, the descriptive statistics were performed in the SPSS (version, 21) in which researcher calculated means, standard deviation to determine the causes of English speaking anxiety among the participants. To answer the second research question cited above, Samples Independent t-test was also run in the SPSS to determine whether or not there was any significant different across gender in terms of English speaking anxiety.

\section{Findings}

The first question aimed at determining the causes of English speaking anxiety among Postgraduate students of 
University of Balochistan, Pakistan. The results of descriptive statistics on three constructs are illustrated below:

Table 2. Anxiety factors relating to Inter-language phonology

\begin{tabular}{lll}
\hline Items & Mean & Std. Deviation \\
\hline I never feel quite sure of myself when I am speaking in my English language class. & 3.40 & 1.08 \\
I keep thinking that the other students have better English accents than I do. & 2.78 & 1.09 \\
I never feel ashamed when other students are hearing my English accent in my language & 3.21 & 1.04 \\
class. & $3.85^{*}$ & 3.21 \\
The more I try to speak English fluently in the class, the more disappointed I get. & $3.55^{* *}$ & 1.07 \\
It worries me when I cannot speak English with a good accent in my language class. & 1.02 \\
I always feel that the other students will laugh at my accent as I speak English in class. &
\end{tabular}

Note. *the highest and ** second highest

After analyzing the items of the above Table 2 based on Inter-language phonology, it was noted that the majority of the students $(M=3.85, S D=0.91)$ attributed their anxiety to the disappointment they develop when try to speak fluently in the English language. This kind of anxiety is likely to emanate when students compare their speaking fluency with fluent students in EFL classroom. Additionally, students $(M=3.55, S D=1.02)$ also reported that they feel anxious of speaking in class for other students laugh at them owing to their poor accent and inefficiency in the structure of the target language.

Table 3. Anxiety factors relating to Inter-language grammar

\begin{tabular}{lll}
\hline Items & Mean & Std. Deviation \\
\hline I usually feel comfortable when using grammar in my speaking in my language class. & 3.42 & 1.08 \\
In my language class, it disturbs me when I cannot speak English very much because of my & $3.79^{* *}$ & 0.96 \\
grammar. & $3.90^{*}$ & 0.82 \\
I would be worried failing to use correct grammar in my speaking in my language class. & 3.38 & 0.99 \\
$\begin{array}{l}\text { I wonder why some people feel very self-conscious when teacher corrects their grammatical } \\
\text { mistakes. }\end{array}$ & \\
When I want to use correct grammar to speak English in the class, I get so nervous that I forget what & 3.82 & 0.94 \\
to say. & 3.61 & 0.98 \\
It frightens me when I cannot speak English without any grammatical mistakes in the class. & &
\end{tabular}
Note. * the highest and $* *$ second highest.

The results of the Table 3illustrate that the EFL learners become anxious when they fail to use correct grammar in their language class $(M=3.90, S D=0.824)$. Furthermore, they also reported that they suffer from anxiety when grammar hinders them from speaking in their language class $(\mathrm{M}=3.79, \mathrm{SD}=0.97)$. In Pakistani context, EFL teacher put undue importance to the grammar of English language. The very over concern to the grammar, students fall prey to anxiety of committing grammatical errors in their speaking.

Table 4. Anxiety factors relating to inter-language meaning system

\begin{tabular}{lll}
\hline Items & Mean & Std. Deviation \\
\hline I become confused when the teacher does not understand what I mean in English. & $3.89^{* *}$ & 0.88 \\
I feel fear when I am not sure of saying something that makes sense in English. & 3.73 & 0.90 \\
I can feel my heart beating when the teacher asks me the question; "what do you mean?" & $4.03^{*}$ & 0.77 \\
While speaking in my language class, I feel afraid when I translate word by word the & 3.76 & 0.95 \\
expressions from my native language into English language. & 3.85 & 1.04 \\
In my language class, I feel pressured when I use English sentences not heard before. & 3.44 & 1.08 \\
I do not feel afraid when the teacher does not understand what I mean in English. &
\end{tabular}

Note. $*$ the highest and $* *$ second highest

In the following table the majority of the learners $(M=4.03, S D=0.77)$ stated that due to their inefficiency in the English language, they cannot raise queries from teachers pertinent to their learning problems. Since English language is the medium of instructions in Pakistani educational institutes, the students are required to speak English in an EFL classroom. The very compulsory nature of English language in Pakistan causes anxiety among 
many inefficient students. Following the majority, the participants showed concerns on their responses not comprehensible for the teacher $(M=3.89, S D=0.89)$.

The second research question was designed to explore whether there is any statistical significant difference between male and female postgraduate students of University of Balochistan, Pakistan, in terms of foreign language speaking anxiety factors. An independent samples t-test was run in SPSS to calculate the statistical significant difference across gender among the above mentioned participants. The following Table 5 presents the findings:

Table 5. Independent samples t-test result

\begin{tabular}{llcccll}
\hline Constructs & Gender & Mean & SD & T & Df & P \\
\hline \multirow{2}{*}{ Overall } & Male & 64.82 & 5.88 & 0.223 & 238 & .0823 \\
& Female & 64.98 & 5.67 & & & \\
\hline
\end{tabular}

It can be viewed from the above Table 5 , that there was no statistical significant difference between male $(M=64.82, S D=5.88)$ and female $[M=64.98, S D=5.67) ; \mathrm{t}(238)=0.223, \mathrm{p}=0.823]$ postgraduate students of University of Balochistan, Pakistan, in terms of FLSA factors. The magnitude of the difference was calculated as eta squared $=0.0021$ which is considered small (Cohen, 1988).

\section{Discussion}

The overall findings indicate that students at tertiary level experience foreign language classroom anxiety due to foreign language speaking classroom activities. Furthermore, the findings of the first research question revealed that the majority of the postgraduate students of University of Balochistan attribute most of their foreign language speaking anxiety to inter-language meaning system. This finding is in line with the findings by Mehmoodzadeh (2012). The fear of communicating with foreign language instructors caused anxiety among learners since they were afraid of committing grammatical errors. The anxiety in learning and producing of foreign language discourse often causes anxiety among FLLs (Aida, 1994; Maclntyre, 1995; Young, 1991). To help learners reduce this kind of anxiety, teachers or instructors should provide support and motivation to these students to make classroom interaction without fear of committing grammatical errors (Woodrow, 2006, p. 323). Following inter-language meaning system, the participants of the study reported inter-language grammar another potential source of anxiety. Majority of the students revealed their concern about their inefficiency in the grammar of the target language that could cause them lose securing good marks in the class speaking activities. Mak (2011) asserted that fear of negative evaluation make many foreign language learners experience anxiety.

To answer the second research question, the findings of the study demonstrated that the difference across the genders among postgraduate students of University of Balochistan was not statistical significant. This finding is in line with the findings of the past studies (Chiang, 2012; Gopang, Bughio, \& Pathan, 2015; Waseem \& Jibeen, 2013, Dewaele, 2007, Erden \& Batumlu, 2007). Since both the male and female students at University of Balochistan come from similar educational and social background, therefore, both males and females were facing similar problems in terms of English speaking anxiety.

\section{Conclusions}

Horwitz et al. (1986) defined anxiety "a distinct complex of self-perceptions, beliefs, and behavior related to classroom language learning arising from the uniqueness of the language learning process" (p. 128). The findings of this study confirmed the above view that the postgraduate students at University of Balochistan, Pakistan experience English speaking anxiety in EFL classroom which have debilitating effects on their academic achievement. This study also suggests more studies on foreign language learning anxiety in general and foreign language speaking anxiety in particular so that in depth knowledge of the factors causing anxiety can be explored and their possible remedies could be recommended.

\section{Implications}

As anxiety retards the learning process among students, this area has been the major concern for many researchers in the world (Awan et al., 2010; Gardener, Moorcroft, \& Macltyre, 1987; Gkonou, 2011; Ohata, 2005; Scovel, 1978; Zheng, 2008). The findings of this study determine that Pakistani students experience anxiety due to the myriad factors which need to be addressed by the higher authorities of Pakistan so that FLL may be provided grounds to lessen their anxiety. This study also benefit the EFL teachers in Pakistan in general and particular in Balochistan province to know the factors which are responsible for causing anxiety among their 
students and these findings could also help Pakistani EFL teachers to devise possible solutions to help students cope with their anxiety. The findings of this research also benefit those scholars who are currently working on anxiety. The last but not the least, this research also contributes to the existing knowledge on anxiety in the world in general and in Pakistan in particular.

\section{References}

Abu-Rabia, S. (2004). Teachers' role, learners' gender differences, and FL anxiety among seventh-grade students studying English as a foreign language. Education Psychology, 24(5), 711-721. https://doi.org/10.1080/0144341042000263006

Aida, Y. (1994). Examination of Horwitz, Horwitz, and Cope's construct of foreign language anxiety: The case $\begin{array}{llllll}\text { students of Japanese. Modern Language Journal, } & \text { 78, }\end{array}$ https://doi.org/10.1111/j.1540-4781.1994.tb02026.x

Awan, R., Azher, M., Anwar, M. N., \& Naz, A. (2010). An investigation of foreign language classroom anxiety and its relationship with students' achievement. Journal of College Teaching \& Learning, 7(11), 33-40. https://doi.org/10.19030/tlc.v7i11.249

Batumlu, D. Z., \& Erden, M. (2007). The relationship between foreign language anxiety and English achievement of Yildı Technical University School of foreign languages preparatory students. Journal of Theory and Practice in Education, 3(1), 24-38.

Bozavli, E., \& Gulmez, R. (2012). Turkish students' perspectives on speaking anxiety in native and non-native english speaker classes. Us-China Education Review, 12, 1034-1043. Retrieved from http://file://C:/Users/Zhaid\%20Khan/Downloads/2013022070353409.pdf

Cohen, J. (1988). Statistical power analysis for the behavioral sciences. Hillsdale, NJ: Erlbaum.

Creswell, J. W. (2002). Educational research: Planning, conducting, and evaluating quantitative. New Jersey: Upper Saddle River.

Dalkiliç, N. (2001). The role of foreign language classroom anxiety in English speaking courses. ÇukurovaÜniversitesiSosyalBilimlerEnstitüsüDergisi, 8(8).

Daly, J. (1991). Understanding communication apprehension: An introduction for language educators. Language anxiety: From theory and research to classroom implications, 3-13.

Daly, J. A. (1997). Avoiding communication: Shyness, reticence, and communication apprehension. Hampton: Pr.Chicago.

Dewaele, J. M. (2007). Predicting language learners' grades in the L1, L2, L3 and L4: the effect of some psychological and socio-cognitive variables. International Journal of Multilingualism, 4(3), 169-197. https://doi.org/10.2167/ijm080.0

Friedman, P. G. (1980). Shyness and reticence in students. Washington, DC: National Education Association.

Gardner, R. C. (1987). The role of anxiety in second language performance of language dropouts. Research Bulletin No. 657. Retrieved from: http://eric.ed.gov/?id=ED323774

Gay, L. R., Mills, G. E., \& Airasian, P. W. (2011). Educational research: Competencies for analysis and applications. Pearson Higher Ed.

Gkonou, C. (2011) Anxiety over EFL speaking and writing: A view from language classrooms. Studies in Second Language Learning and Teaching, 1(2), 267-281. https://doi.org/10.14746/ssllt.2011.1.2.6

Gopang, I. B., Bughio, F. A., \& Pathan, H. (2015). Investigating Foreign Language Learning Anxiety among Students Learning English in a Public Sector University, Pakistan. Malaysian Online Journal of Educational Sciences, 3(4), 27-38.

Horwitz, E. K., \& Young, D. J. (1991). Language anxiety: From theory and research to classroom implications. Pearson College Div.

Horwitz, E., Horwitz, M., \& Cope, J. (1986). Foreign language classroom anxiety. The Modern Language Journal, 70, 125-132. https://doi.org/10.1111/j.1540-4781.1986.tb05256.x

Iftimie, N. M. (2006). Working in an Asian university: Expecting the unexpected. BuletinulInstitutuluiPolitehnic din Iasi, LII(5).

MacIntyre, P. D. (1995). How does anxiety affect second language learning? A reply to Sparks and Ganschow. 
Modern Language Journal, 79(1), 90-99. https://doi.org/10.1111/j.1540-4781.1995.tb05418.x

Mak, B. (2011). An exploration of speaking-in-class anxiety with Chinese ESL learners. System, 39(2), 202-214. https://doi.org/10.1016/j.system.2011.04.002

Mehmoodzadeh, M. (2012). Investigating foreign language speaking anxiety within the EFL learner's inter-language system: The case of Iranian learners. Journal of Language Teaching and Research, 3(3), 466-476.

Oh, J. (1990). On the relationship between anxiety and reading in English as a foreign language among Korean university students in Korea. Unpublished doctoral dissertation. University of Texas at Austin.

Ohata, K. (2005). Potential sources of anxiety for Japanese learners of English: Preliminary case of interviews with five Japanese college students in the US. TESL-EJ, 9(3), 2-23.

Öztürk,G. (2009). Foreign Language Speaking Anxiety and Learner Motivation: A Case Study at a Turkish State University (Unpublished master's thesis). METU, Ankara.

Phillips, E. M. (1999). Decreasing language anxiety: Practical techniques for oral activities. Affect in foreign language and second language learning: A practical guide to creating a low-anxiety classroom atmosphere, 124-143.

Price, M. L. (1991). The Subjective Experience of Foreign Language Anxiety: Interviews with Highly Anxious Students. In E. K. Horwitz \& D. J. Young (Eds.), Language Anxiety.

Saltan, F. (2003). EFL speaking anxiety: How do students and teachers perceive it? (Unpublished master's thesis), METU, Ankara.

Scovel, T. (1978). The effect of affect on foreign language learning: a review of the anxiety research. Language Learning, 28(1), 129-142. https://doi.org/10.1111/j.1467-1770.1978.tb00309.x

Scovel, T. (1991). The effect of affect on foreign language learning: A review of the anxiety research. In E. K. Horwitz \& D. J. Young (Eds.), Language anxiety: From theory and research to classroom implications (pp. 15-28). Englewood Cliffs: Prentice Hall.

Spolsky, B. (1989). Communicative competence, language proficiency and beyond. Applied Psycholinguistics, 10, 138-156. https://doi.org/10.1093/applin/10.2.138

Tercan, G., \& Dikilitas, K. (2015). EFL students' speaking anxiety: A case from tertiary level students. International Association of Research in Foreign Language Education and Applied Linguistic ELT Research Journal, 4(1), 16-27.

Timina, S. (2015). Causes of English Speaking Anxiety among Taiwanese University Students: Proceedings of INTCESS 15-2nd International Conference on Education and Social Science. 1305-1309.

Waseem, F., \& Jibeen, T. (2013). Anxiety amongst learners of English as a second language: An examination of motivational patterns in the Pakistani context. International Journal of Humanities and Social Science, 3(16), 174-184.

Woodrow, L. (2006). Anxiety and speaking English as a second language. RELC journal, 37(3), 308-328. https://doi.org/10.1177/0033688206071315

Young, D. J. (1986). The relationship between anxiety and foreign language oral proficiency ratings. Foreign Language Annals, 19(5), 439-445. https://doi.org/10.1111/j.1944-9720.1986.tb01032.x

Young, D. J. (1990). An investigation of students' perspectives on anxiety and speaking. Foreign Language Annals, 23(6), 539-553. https://doi.org/10.1111/j.1944-9720.1990.tb00424.x

Zhao, N. (2007). A study of High school Students' English Learning Anxiety. The Asian EFL Journal, 9(3), $22-34$.

Zheng, Y. (2008) Anxiety and second /foreign language learning revisited. Canadian Journal for New Scholars in Education, 1(1), 1-12.

\section{Copyrights}

Copyright for this article is retained by the author(s), with first publication rights granted to the journal.

This is an open-access article distributed under the terms and conditions of the Creative Commons Attribution license (http://creativecommons.org/licenses/by/4.0/). 